\title{
Changes in REIT Liquidity 1990-94: Evidence from Intra-day Transactions*
}

\author{
Vijay Bhasin \\ Board of Governors of the Federal Reserve System, Washington, DC 20551, USA \\ Rebel A. Cole \\ Board of Governors of the Federal Reserve System, Washington, DC 20551, USA \\ Joseph K. Kiely \\ School of Business, Eastern Carolina University, Greenville, NC 00000, USA
}

Abstract: In this study, we use data on intra-day transactions to analyze whether REIT liquidity as measured by the bid-ask spread changed from 1990 to 1994, a period during which the industry's market capitalization increased from $\$ 9$ billion to $\$ 45$ billion. We find that REIT spreads narrowed significantly. We then use a variation of the empirical model proposed by Stoll (1978) to analyze the determinants of percentage spreads including whether spreads are determined by return variability, share price, exchange listing, and asset type. We find strong support for Stoll's model, in that return variance and share price are the primary determinants of percentage spreads in both periods analyzed. This suggests that the liquidity of REIT securities is similar to that of non-REIT securities with similar prices and return variance. In addition, we find that percentage spreads are wider for REITs trading on NASDAQ. In contrast with an earlier study, we find that market capitalization is not a significant determinant of REIT percentage spreads.

Key words: bid-ask spread, liquidity, REIT

JEL Classification: G11, G23, G32

Correspondence to: Rebel A. Cole, Mail Stop 90, Board of Governors of the Federal Reserve System, Washington, DC 20551 or e-mail to m1rac01@frb.gov

\footnotetext{
* We thank Paul Kupiec and Steve Lumpkin for helpful discussion of the issues analyzed in this study. The analysis and views in this paper are those of the authors and do not indicate concurrence by the Board of Governors or the Federal Reserve System.
} 


\section{Changes in REIT Liquidity 1990-94: Evidence from Intra-day Transactions}

\section{Introduction}

From 1990-94, the market capitalization of all tax-qualified real estate investment trusts (REITs) increased from $\$ 8.7$ billion to $\$ 44.3$ billion, an increase of more than $500 \%$. The industry effectively doubled in size from $1990-92$ (from $\$ 8.7$ billion to $\$ 15.7$ billion) and then doubled again during 1993 (to $\$ 32.1$ billion). Much of this explosive growth is attributable to the switch from private to public ownership of commercial real estate following the industry bust in the late 1980s. The switch from private to public ownership has been fueled in large part by the growing involvement of institutional investors seeking a more liquid vehicle for diversifying into commercial real estate. These investors, who were unable to liquidate their holdings in commingled real estate funds in a timely manner when the commercial real estate market tanked in the late 1980s, view REITs as a less risky vehicle for incorporating commercial real estate into their predominantly stock and bond portfolios.

The claim that REITs offer greater liquidity than other real estate investment vehicles has not gone unchallenged. Many practitioners and academics argue that REITs are much less liquid than proponents claim, pointing out that the market capitalization of most REITs is small enough that the typical-sized trade of an institutional investor could significantly affect transaction prices. Indeed, if multiple large investors were to attempt to sell their shares in response to a cyclical downswing, or simply as a sunspot response, they would only be able to do so at firesale prices. This paper contributes to this debate by examining the changes in REIT liquidity during the 1990s. The measure of liquidity adopted here is the difference between a security's bid and ask prices, or the bid-ask spread. Amihud and Mendelson (1986) state "Illiquidity can be measured by the cost of immediate execution." They go on to say "a 
natural measure of illiquidity is the spread between the bid and ask prices." Hence, larger bid-ask spreads are widely regarded as evidence of more illiquid securities. Demsetz (1968) was the first to analyze bid-ask spreads empirically, and numerous researchers have followed his pathbreaking work. ${ }^{1}$

Nelling et al. (1995) provide some evidence on the liquidity of REITs as measured by the bid-ask spread. They show that during 1990 REIT bid-ask spreads are similar to the spreads on equities of similar size. ${ }^{2}$ Somewhat disconcertingly (for the REIT industry), they also document reductions in REIT liquidity as measured by bid-ask spreads over the 1986-90 period. However, that period predates the explosive growth in the REIT market during 199094, suggesting that a reexamination of REIT liquidity is in order. We hypothesize that this growth was accompanied by increases in REIT liquidity in part because of the entry in to the market of large institutional investors. Consequently, we examine changes in REIT liquidity as measured by the bid-ask spreads of all publicly traded REITs from 1990 to 1994.

One reason for an increased participation in the REIT market by institutional investors is that larger market capitalization REIT's became available, thereby offering instituitonal investors with the opportunity to purchase meaningful chunks of commercial real estate. Another reason is that the "five or fewer" restriction which states that no more than $50 \%$ of a REIT's stock could be held by five or fewer investors has essentially been relaxed. New

1 It should be kept in mind that bid-ask spreads are only one measure of liquidity. In particular, bid-ask spreads can be poor measure of liquidity if one desires immediacy for large positions. See Bhasin (1996) for a discussion of the shortcomings of bid-ask spread and for an alternative measure of liquidity.

2 In contrast, Below, Kiely, and McIntosh (1995) find that during 1991 spreads on equity REITs were significantly wider than those on similar non-REIT stocks. 
legislation in 1993 directed the IRS to "look through" a large pension investor to the number of individual pension fund participants when applying the rule, thereby opening the door to increased institutional investment in REITs.

As the interest of institutional investors in REITs has increased, so has the interest of investment firms covering the REIT industry. With more investment firms covering each REIT, informational asymmetries between uninformed and informed traders should be reduced. Since informational asymmetries impose adverse selection costs on the market makers, and are recovered through the bid-ask spreads, a reduction in informational asymmetries, should cause the bid-ask spreads to decrease. ${ }^{3}$

\section{Data}

The initial sample of REITs was identified using the 1992 and 1995 editions of the REIT Handbook, which is published by the National Association of Real Estate Investment Trusts. The REIT Handbook provides detailed information on all tax-qualified REITs. ${ }^{4}$ From this information we identified all REITs that traded on the New York Stock Exchange (NYSE), the American Stock Exchange (AMEX), or the NASDAQ market. ${ }^{5}$ This produced

3 See, for example, Glosten and Milgrom (1985), Easley and O'Hara (1987), and Kyle (1985).

4 The 1992 edition was used to identify REITs in existence as of year-end 1990, and the 1995 edition was used to identify REITs in existence as of year-end 1994. The 1992 edition was used because there was no 1991 edition. The 1992 edition identifies REITs that began trading after year-end 1990 and provides year-end 1990 data on invested assets and market capitalization.

5 The REIT Handbook also identifies "other over-the-counter stocks," but we chose to limit our analysis to stocks trading on the NYSE, the AMEX, or NASDAQ exchanges. 
samples of 117 and 223 REITs for 1990 and 1994, respectively. The information in the REIT Handbook was used to identify the exchange on which each REIT traded; whether a REIT was classified as an equity, mortgage, or hybrid REIT; as well as the year-end market capitalization. ${ }^{6}$

Table 1 shows the numbers and market capitalization of the two sample years by asset type and exchange. During 1990, 44\% of the 117 tax-qualified REITs traded on the NYSE, while $34 \%$ traded on the AMEX. The remaining $14 \%$ traded on the NASDAQ. Market capitalization was clearly skewed toward the NYSE, which accounted for $74 \%$ of the $\$ 8.7$ billion industry total, while the NASDAQ accounted for only $9 \%$. By asset type, almost half of the 117 REITs were classified as equity specialists, just over a third as mortgage specialists, and the remainder as hybrids. Market capitalization was similarly distributed.

During 1994, more than $60 \%$ of the 223 tax-qualified REITs traded on the NYSE, and these REITs accounted for more than $90 \%$ of the industry capitalization. Only $11 \%$ of REITs traded on NASDAQ, and these 24 firms accounted for but $3 \%$ of the industry's $\$ 44.6$ billion market capitalization. By asset type, four of five REITs were classified as equity specialists. These 178 firms also accounted for $88 \%$ of the industry's market capitalization. Thus, the bulk of the growth in the REIT industry was accounted for by equity REITs.

Next, our initial samples of firms were cross-referenced with lists of firms from the Institute for the Study of Securities Market (ISSM) 1990 transaction file and from the Trading

6 NAREIT classifies REITs by asset type based upon the distribution of its invested assets. REITs holding at least $75 \%$ of invested assets in the form of equity is classified as an equity REIT, whereas a REIT holding at lest $75 \%$ of invested assets in the form of mortgages if classified as a mortgage REIT. All other REITs are classified as hybrid REITs. 
and Quotes (TAQ) 1994 transaction file. We were able to obtain data necessary to calculate bid-ask spreads for all but three of the firms in our initial samples. ${ }^{7}$ The 1990 and 1994 transaction files were also used to obtain data necessary to calculate daily averages for price and volume.

Two alternative measures of the bid-ask spread were calculated: a dollar spread and a percentage spread. The dollar spread is the daily average dollar spread, while the percentage spread is the dollar spread divided by the daily average share price. We use daily averages because Harris (1989) has shown that the last transaction of the day tends to occur at the asking price which can bias the results. The daily spread measurement for the firm is then averaged over all trading days in each year.

Table 2 presents cross-sectional descriptive statistics for our two sample years. In this table, we see that the average daily return variance fell from $18 \%$ in 1990 to $7 \%$ in 1994 , a decline of more than $60 \%$. Average daily volume almost tripled from 11 thousand shares in 1990 to more than 30 thousand shares in 1994 . Average daily turnover (dollar volume divided by market capitalization) increased from $0.19 \%$ to $0.27 \%$. Average share price increased from $\$ 9$ to $\$ 15$ and market value increased from $\$ 74$ million to $\$ 200$ million. Shares outstanding (not shown) increased from 11 million to only 12.6 million, implying that most of the increase in market value was due to increases share prices. (Differences in the

7 The 1990 ISSM tapes contained no transaction price data for three sample securities: CEDR, CMRT, and PDLA. Consequently, these three firms were excluded from the remainder of our analysis. Since in aggregate these three firms accounted for only $\$ 23$ million in market capitalization, we expect their exclusion has negligible effect on our results. 
distributions of REITs across exchanges and asset types were explored in the discussion in Table 1.)

\section{Univariate results}

Table 3 presents average bid-ask spreads as a percentage of share price for the industry and by asset type and exchange. Overall, the percentage bid-ask spread declined from $5.63 \%$ in 1990 to $4.30 \%$ in 1994 . The results of a $t$-test for difference in means indicates that this $1.32 \%$ difference is statistically significant at the 0.05 level.

Panel A shows that the overall decline in percentage spreads is largely attributable to the spreads of NASDAQ REITs, which declined 3.94 percentage points from $11.64 \%$ to 7 . 70\%. Spreads on NYSE REITs declined 0.45 percentage points from $3.88 \%$ to $3.43 \%$, while spreads on AMEX REITs increased by 0.44 percentage points from $4.43 \%$ to $4.87 \%$. All of these differences are statistically significant.

Panel B shows that this decline has not been uniform across asset types. Indeed, it is attributable almost entirely to the decline in the spreads of equity REITs, which fell 1.02 percentage points from $4.49 \%$ to $3.47 \%$. Spreads on mortgage REITs actually increased over this time period from $6.02 \%$ to $6.95 \%$, while spreads of hybrid REITs declined only 0.05 percentage points from $8.61 \%$. The decline in equity REIT spreads and the increase in the mortgage REIT spreads were highly significant, while the change in the hybrid REIT spreads was insignificant. 
To investigate whether the declines in percentage spreads over the 1990-1994 period were driven by declines in the numerator (the dollar-value spread), the denominator (share price), or both, Table 4 presents average dollar-value spreads instead of percentage spreads. As shown at the top of Table 4, the average dollar spread actually widened from 30 cents to 35 cents during the 1990-1994 period, a 5 cent difference that is statistically significant at the 0.10 level. Panel A shows that dollar spreads increased for all three asset types, but only the increase for mortgage REITs (from 23 cents to 31 cents) is statistically significant. Panel B shows that dollar spreads increased for both NYSE and AMEX REITs, but declined for NASDAQ REITs. Only the NYSE increase (from 24 cents to 35 cents), however, is statistically significant. As a whole, the results in Table 4 show that REIT dollar spreads were constant or increasing during the 1990-1994 period. Therefore, the declines in the percentage spreads observed in Table 3 must be attributed to increases in share prices rather than to declines in dollar spreads.

While the results in Tables 3 and 4 are informative measures of REIT liquidity, they do not reflect the actual spreads that would have been faced by an investor interested in transacting a portfolio representative of the REIT industry. In the following paragraphs, we discuss measures of the dollar (or equivalently, percentage) transaction cost paid by an investor in constructing equally weighted and value-weighted portfolios with market values of $\$ 100{ }^{8}$ The dollar spread paid for the equally weighted portfolio is:

8 The measures assume that the shares of REITs are infinitely divisible, i.e., the investor can buy or sell fractional shares. This assumption is without loss of generality. Under an alternative assumption, eq. (2) and eq. (5) below measure the transaction costs that should be allocated for each $\$ 100$ invested in REIT index mutual funds which replicate the (hypothetical) equally weighted and value-weighted REIT indices. 


$$
\text { Equally weighted portfolio spread }=\Sigma_{\mathrm{i}=1}^{\mathrm{N}} \operatorname{Spread}_{\mathrm{i}} * \text { Shares }_{\mathrm{i}} \text {, }
$$

where Equally weighted portfolio spread is the dollar spread costs that would be incurred while constructing a portfolio with a market value of $\$ 100$ containing an equal number of shares of each REIT trading in each group. Spread $_{i}$ is the quoted dollar bid-ask spreadaveraged over all quotes in the year for stock $i$ and Shares $_{i}$ is the number of shares of stock $i$ in the portfolio. The number of shares of each stock purchased in the equally weighted portfolio is the market value of the portfolio $(\$ 100)$ divided by the sum of each stock's price, where price is the transaction price averaged over all transactions in the year for stock $i$. Eq. (1) can be rewritten as:

$$
\underset{\text { pqually weighted }}{\text { portfolio spread }}=100 * \frac{\sum_{i=1}^{N} \text { Spread }_{i}}{\sum_{i=1}^{N} \text { Price }_{i}}
$$

It is important to note that the equally weighted portfolio spread shown above is not the same as the average percentage spread presented in Table 3. The average percentage spread is calculated as:

$$
\text { Average percentage spread }=100 * \Sigma_{i=1}^{N} \frac{\text { Spread }_{i}}{\text { Price }_{i}}
$$


As shown in Table 5, for all REITs the equally weighted portfolio spreads declined during the 1990-1994 period by 93 cents from $\$ 3.29$ per $\$ 100$ to $\$ 2.36$ per $\$ 100$. Hence, transaction costs fell by more than $28 \%$, strong evidence of increased liquidity in the REIT market. Panel A presents portfolio spreads by exchange. As shown in this panel, the spread on an equally weighted NYSE REIT portfolio declined from $\$ 2.18$ per $\$ 100$ to $\$ 1.96$ per $\$ 100$ or about $10 \%$. The spread on an equally weighted NASDAQ REIT portfolio declined from $\$ 8.08$ per $\$ 100$ to $\$ 5.54$ per $\$ 100$ or more than $30 \%$. The spread on an equally weighted AMEX REIT portfolio was up slightly but essentially unchanged.

As shown in panel B, the decline in spreads by asset type was confined to equity and hybrid REITs. For an equally weighted equity REIT portfolio, the spread declined from $\$ 2.88$ per $\$ 100$ to $\$ 2.19$ per $\$ 100$, a decline of $24 \%$. For an equally weighted hybrid REIT portfolio, the spread declined from $\$ 5.14$ per $\$ 100$ to $\$ 3.35$ per $\$ 100$, a decline of almost half. In contrast, the spread for an equally weighted mortgage REIT portfolio actually increased slightly from $\$ 3.57$ per $\$ 100$ to $\$ 3.70$ per $\$ 100$.

Also in Table 5 are the spread costs incurred while constructing a value-weighted REIT portfolio with a market value of $\$ 100$. The dollar spread paid for the value-weighted portfolio is:

$$
\underset{\text { portfolio spread }}{\text { Value weighted }}=\Sigma_{i=1}^{N} \text { Spread }_{i} * \text { Shares }_{i} \text {, }
$$


where Value weighted portfolio spread is the dollar spread that would be paid by construction a portfolio with a market value of $\$ 100$ allocated proportionally by the market capitalization across all REITs trading in each group in a given year, Spread $_{i}$ is the quoted dollar bid-ask spread averaged over all quotes in the year for stock $i$, and Shares ${ }_{i}$ is the number of shares of stock $i$ in the portfolio. The number of shares of each stock in a value-weighted portfolio is calculated as

$$
\text { Shares }_{i}=\left[100 * \frac{\left(\text { Market capitalization }_{i} \div \Sigma_{i=1}^{N} \text { Market capitalization }_{i}\right)}{\text { Price }_{i}}\right]
$$

The number of shares of each stock in the portfolio is the dollar investment in each stock in the portfolio divided by each stock's price. The dollar investment in each stock is 100 times the market value fraction, which is the ratio of the stock's market capitalization to that of the group. Inserting eq. (5) into eq. (4) and rearranging terms, we obtain:

$$
\underset{\text { paltue-weighted }}{\text { portfolio spread }}=\Sigma_{i=1}^{\mathrm{N}}\left[100 * \frac{\text { Spread }_{\mathrm{i}}}{\text { Price }_{\mathrm{i}}} * \frac{\text { Market capitalization }_{\mathrm{i}}}{\Sigma_{\mathrm{i}=1}^{\mathrm{N}} \text { Market capitalization }_{\mathrm{i}}}\right]
$$

From eq. (6), we see that the value-weighted percentage portfolio spread is equal to the valueweighted individual stock percentage spread.

For all REITs, the value-weighted percentage spread declined from $1.97 \%$ in 1990 to 1.89\% in 1994. Panel A shows that from 1990 to 1994, the value-weighted percentage spreads declined only modestly for NYSE listed REITs, increased by 63 basis points for AMEX 
$-11-$

REITs, and declined by 216 basis points for hybrid REITs. Panel B shows a similar pattern in value-weighted percentage spreads by REIT type. These spreads declined slightly for equity REITs, increased by 81 basis points for mortgage REITs, and declined by 294 basis points for hybrid REITs. These results suggest that increases in REIT liquidity were most pronounced for hybrid REITs and for REITs trading on NASDAQ.

To summarize, we find that average percentage spreads declined significantly from 1990 to 1994 , and that these declines were driven by changes in share prices rather than changes in dollar spreads. In a portfolio context, we find that the dollar spreads on $\$ 100$ equally weighted and value-weighted REIT portfolios declined overall, for equity and hybrid but not mortgage REITs, and for NYSE and NASD but not AMEX REITs. This evidence suggests that the overall liquidity of REITs increased during this period, but that this increased liquidity was not uniform across asset type or exchange listing.

\section{Regression methodology}

Next, we use ordinary-least-squares regressions to explain determinants of the bid-ask spread for the 1990 and 1994 samples and to test whether the observed cross-sectional relationship are stable across the two time periods. We follow Chiang and Venkatesh (1988) in using the empirical work of Stoll (1978) as the basis for our model of the spread.

Bid-ask spreads compensate market makers for the costs incurred while providing inter-temporal liquidity to prospective buyers and sellers. Market makers incur fixed, inventory and adverse information costs during trading. Fixed costs include back office and paper work costs. Inventory costs are incurred when market makers buy or sell from personal 
inventory and bear the risk of random price changes. Adverse selection costs exist because market makers are unable to distinguish between informed and un-informed investors. Positive spreads allow the market makers to recover losses due to trading with informed traders from uninformed traders.

In Stoll's empirical model, the holding cost component is proxied by return variance and volume variables. Holding or inventory costs incurred by a dealer depend upon the risks assumed by the dealer, which increase with the variability of a stock's return and the holding period. ${ }^{2}$ In turn, holding periods are likely to be functions of trading volume since the dealer can more easily reverse a position when the stock is actively traded. Consequently, the percentage spread is expected to be an increasing function of the variance of returns and a decreasing function of trading volume. Stoll includes turnover (defined as dollar volume divided by market capitalization) as a proxy for adverse information costs. If in the absence of information, investors trade in amounts proportional to stock outstanding, then, if private information is available, trading in those stocks about which investors have private information should exceed other stocks, leading to a higher level of turnover in that stock. The variability of a stock's return might also proxy for adverse information. Percentage spreads are expected to be a positively associated with turnover and return variability. ${ }^{10}$ Stoll includes price per share as a proxy for unobservable minimum order cost, expecting a

\footnotetext{
9 Note that due to their role as providers of liquidity, dealers are limited in their ability to diversify their positions.

10 The predicted sign on return variability due to adverse information is the same as that due to the holding cost component - if there exists an investor with an informational advantage, the advantage would increase with the variability of the asset for which he has the information, e.g. Kyle (1985).
} 
negative relationship with the percentage spread as the minimum cost is distributed across more dollars for higher priced stocks. Spreads are expected to show a decreasing relationship with price. ${ }^{11}$

Our basic model specification includes four variables tariance of stock returns, volume, price, and turnover. This specification is augmented with five additional variables. The first augmenting variable is a measure of size (market value of equity) because Chiang and Venkatesh (1988) find this variable important in explaining spreads. In addition, Nelling et al. (1995) report that market capitalization is the primary determinant of REIT bid-ask spreads. Both studies report a negative relationship between market value and spreads so we also expect a negative relationship. Second, we include two dummy variables indicating whether a stock trades on the AMEX or NASDAQ exchanges as opposed to the NYSE. Kadlec and McConnell (1994) have documented that a listing on the NYSE reduces spreads. We expect each of these to be positive. Finally, we include two dummy variables for REIT asset type (mortgage and hybrid) to test whether spreads on these types of REITs are different from spreads on equity REITs. Nelling et al. (1995) report significantly lower spreads for equity REITs, so we expect our dummies for mortgage and hybrid REITs to be positive. Our full model specification is:

\footnotetext{
11 Stoll's model also includes variables that proxy for competition among dealers and dealer wealth.
} 


$$
\begin{aligned}
& \text { Spread }_{i, t}=\alpha+\beta_{1} \text { Return Variance }_{i, t}+\beta_{2} \text { Volume }_{i, t} \\
& +\beta_{3} \text { Turnover }_{i, t}+\beta_{4} \text { Share Price }_{i, t}+\beta_{5} \text { Market Value }_{i, t} \\
& +\beta_{6} \text { AMEX }_{i, t}+\beta_{7} \text { NASDAQ }_{i, t} \\
& +\beta_{8} \text { Mortgage }_{i, t}+\beta_{9} \text { Hybrid }_{i, t}
\end{aligned}
$$

where $\operatorname{Spread}_{i, t}$ is the average percentage bid-ask spread for firm $i$ in year $t$; Return Variance $_{i, t}$ is the variance of the daily return on stock $i$ in year $t$; Volume $e_{i, t}$ is the average daily volume for stock $i$ in year $t$; Turnover $_{i, t}$ is the average daily dollar volume of stock $i$ as a percentage of its market capitalization in year $t$, Share Price $_{i, t}$ is the average daily share price for stock $i$ in year $t$; Market Value $_{i, t}$ is the market capitalization for stock $i$ in year $t$; $A M E X_{i, t}$ is a dummy variable indicating that stock $i$ trades on the American Stock Exchange in year $t ; N A S D A Q_{i, t}$ is a dummy variable indicating that stock $i$ trades on the NASDAQ exchange in year $t$; Mortgage $_{i, t}$ is a dummy variable indicating that stock $i$ was a mortgage REIT in year $t$; and Hybrid $_{i, t}$ is a dummy variable indicating that stock $i$ was a hybrid REIT in year $t$. Given this specification, dummy variables measure spread differences relative to an equity REIT trading on the NYSE. To gain efficiency, we pool the 1990 and 1994 samples using a full set of dummy interaction terms for both 1990 and 1994. Pooling also enables us to test whether each variable's coefficients for 1990 and 1994 are different. $^{12}$

This methodology enables us to test whether the differences in 1990 and 1994 spreads reported in Table 3 are (1) due to changes in the independent variables over the same period,

12 Results obtained from performing separate regressions for 1990 and 1994 are not qualitatively different from the pooled results, although significance levels are somewhat lower. 
(2) due to changes in the underlying relationship between spreads and the independent variable, or (3) due to other unexplained factors. If spread differences are attributable to changes in the variables, then we should observe differences across years in the variable means but not in the parameter estimates of those variables. Changes in the underlying relationship between spreads and the explanatory variables would show up as differences across years in the parameter estimates for a given variable. Finally, differences in spreads due to unexplained factors would show up as differences in the intercepts for the two years. The results of this analysis provide insights into the factors to which the observed differences in 1990 and 1994 spreads can be attributed. This has important implications for institutional investors seeking a more liquid vehicle for including commercial real estate assets in their portfolios.

\section{Univariate regression results}

First, we perform separate univariate regressions to analyze the effect of the explanatory variables on percentage spreads in each of these two years. Because an analysis of the raw data suggested that non-linearities were present in the data, specification (7) was also tested on logarithmic transforms of the variables. Tables 6 and 7 contain the results for the transformed and the non-transformed variables.

For the non-transformed data, parameter estimates and the associated $t$-statistics for 1990 appear in the third column of Table 6. These results indicate that return variance is positively related to percentage spreads and that volume, turnover, share price, and market capitalization are each negatively related to percentage spreads. With the exception of 
turnover, each of these variables is statistically significant at least at the 0.05 level. The parameter estimates imply that for each percentage point increase in return variance, spreads increase by 15 basis points; for each 1,000 share increase in daily volume, spreads decline by 13 basis points; for each additional dollar of share price, spreads decline by 49 basis points, and for each $\$ 1$ million increase in market capitalization, spreads decline by 1.7 basis points. Univariate regression results for the exchange and asset-type dummy variables show that only the dummies for AMEX and mortgage REITs are not statistically significant. The NYSE and equity dummies are negative and significant, indicating that such REITs traded at narrower spreads than other REITs during 1990, whereas the NASDAQ and hybrid dummies are positive and significant, indicating that these REITs traded at wider spreads than other REITs during 1990. Of all these variables, the variance of returns explains by far the greatest percentage variation in 1990 spreads, as evidenced by an adjusted- $\mathrm{R}^{2}$ of 0.63 .

Parameter estimates and their associated $t$-statistics for 1994 appear in column 6 of Table 6. Each variable statistically significant in explaining 1990 spreads also is significant in explaining 1994 spreads and has the same sign. In addition, turnover is negative and significant while the mortgage dummy is positive and significant. Coefficients generally are smaller and have larger $t$-statistics, but this may be attributable to the approximate doubling of sample size from 1990 to 1994.

Table 7 presents univariate regression results based upon the logarithmic transforms of the original continuous variables for percentage spread, return variance, volume, turnover, share price, and market capitalization. In general, the results are in keeping with those presented in Table 6 with one important exception. The logarithmic transformations greatly 
increase the explanatory power of return variance, price, and market value. The adjusted- $\mathrm{R}^{2}$ for return variance rises from 0.63 in Table 6 to 0.78 in Table 7, indicating that this risk measure explains more than three-fourths of the variability in log percentage spreads. For share price, the adjusted- $\mathrm{R}^{2}$ rises from 0.25 in Table 6 to 0.69 in Table 7, and, for market capitalization, from 0.10 to 0.59 .

\section{Multivariate regression results}

Next, we perform multivariate regressions on the pooled data to test whether the relationships observed in Tables 6 and 7 hold up after controlling for other variables. Results based upon the non-transformed 1990 data appear in column 2 of Table 8. These results show that only three of our explanatory variables return variance, share price, and the NASDAQ dummyare statistically significant at least at the 0.01 level. Return variance has a coefficient of 0.12 , indicating that spreads were 12 basis points wider for each percentage point increase in return variance. Share price has a coefficient of -0.35 , indicating that spread narrow by 35 basis points for each dollar increase in price. And the NASDAQ dummy has a coefficient of 3.79, indicating that spreads of NASDAQ REITs were 379 basis points wider than those of other REITs. ${ }^{13}$

Results based upon the non-transformed 1994 data appear in column 3 of Table 8. These results show that only three of our explanatory variables Teturn variance, share price, and the AMEX dummyare significant at least at the 0.01 level. As in 1990, return variance

13 The dummy for hybrid REITs is significant at the 0.05 level, but regression diagnostics reveal that variable is unduly influenced by a single observation (CMETS). 
is positive while share price is negative. In addition, the AMEX dummy is negative. The coefficient on return variance rises from 0.12 in 1990 to 0.19 in 1994 , while the coefficient of share price changes from -0.35 in 1990 to -0.28 in 1994 . The AMEX coefficient of -2.23 indicates that spreads of AMEX stocks were 223 basis points narrower than those of stocks trading on the NYSE or NASDAQ.

The last column of Table 8 provides $t$-statistics from a test of whether the variable coefficients for 1994 are significantly different from those for 1990 . These test statistics indicate significant increases in the coefficients of return variance and the hybrid dummy and significant declines in the coefficients of AMEX and NASDAQ dummies. The adjusted-R ${ }^{2}$ for this pooled specification is 0.71 .

Table 9 presents results for 1990 and 1994 based upon the logarithmic transforms of the percentage spread, return variance, volume, turnover, share price, and market capitalization. Overall, this specification explains almost $90 \%$ of the variability in percentage spreads, leading us to reject the non-transformed specification presented in Table 8 , which explains only $70 \%$ of the variability of percentage spreads. The results for 1990 appear in column 2, and show that only three variables return variance, share price, and the NASDAQ dummy $\rightarrow$ are statistically significant at least at the 0.01 level. As expected, return variance and the NASDAQ dummy are positive while share price is negative. Interestingly, log market value is negative but lacks statistical significance. Without the log transform, market value is positive but insignificant. This calls into question the conclusion of Nelling et al. that "market capitalization is the primary determinant of REIT bid-ask spreads". In fact, market capitalization is a significant determinant of REIT bid-ask spreads only when share 
price is omitted from the specification. And even when we exclude share price from our model, return variance rather than market capitalization is the primary determinant of REIT bid-ask spreads. A resolution between our and Nelling et al.'s results can be obtained by acknowledging the role played by share price in explaining percentage spreads. Since price dominates market value in explaining percentage spreads, and the correlation between these two variables is very high, the significance of market value in earlier work can be attributed to model mis-specification, i.e., the omission of share price. ${ }^{14}$

The results for 1994, which appear in column 3, show the same three variables significant in explaining 1990 spreads are statistically significant in explaining 1994 spreads, again with the expected signs. In addition, the AMEX dummy is negative and significant, indicating that spreads on AMEX stocks were significantly lower during 1994 than spreads on other stocks. In the last column of Table 9 are test statistics from a $t$-test for differences in the 1990 and 1994 coefficients. These statistics indicate that only the AMEX coefficient is significantly different in 1990 and 1994. This stability of coefficients over the time period is strong evidence that the decline in spreads documented in Table 3 are attributable to changes in the values of the explanatory variables rather than to a fundamental change in the underlying relationship between spreads and the explanatory variables or than to unexplained factors. Indeed, with an adjusted $\mathrm{R}^{2}$ of 0.89 , there is very little variation in spreads left to explain. A check of Table 2 provides added support for this conclusion. Looking at the three variables significant in both periods, we see that the average return variance dropped from

14 The Pearson product-moment correlation between price and market value is 0.66 for the 1990 sample and 0.65 for the 1994 sample. 
$18 \%$ to $7 \%$, average share price rose from $\$ 9$ to $\$ 15$, and the percentage of firms trading on the NASDAQ declined from $20 \%$ to $11 \%$.

In summary, our analysis of the determinants of bid-ask spreads shows that a variation of the empirical model proposed by Stoll (1978) explains almost $90 \%$ of the variability in spreads, that this model is stable over time, and that the primary determinants are the variance of daily returns, share price, and exchange listing. These results are largely consistent with other studies in the finance literature that have analyzed the percentage spreads of non-REIT stocks, and suggest that there is nothing "different" about the determinants of REIT liquidity. Also, our findings contradict the earlier claims of Nelling et al. that market capitalization is the primary determinants of 1990 REIT bid-ask spreads, and that 1990 spreads were lower for equity REITs. We attribute this to the possibility that market value proxies for share price in their model.

\section{Conclusions}

In this study, we examine the bid-ask spreads of REITs for evidence whether the liquidity of REITs increased over the 1990-94 period. This was an important period for the REIT industry, during which the industry's market capitalization quintupled. Our analysis shows that REIT liquidity increased significantly from 1990 to 1994 . Our findings have important implications for institutional and other investors as they seek more liquid vehicles

for diversifying into commercial real estate. First, our results show that the costs of acquiring or liquidating commercial real estate holdings in the form of REIT equity securities have fallen as the size of the REIT market has grown. Second, we show that the primary 
determinants of REIT spreads are risk (as measured by the variance of daily stock returns), share price, and exchange listing. Greater variance gives rise to wider spreads, while higher share prices give rise to lower spreads.

REITs listed on NASDAQ have wider spreads than those listed on the NYSE and AMEX. In general, we find that the determinants of bid-ask spreads were stable from 1990 to 1994, with one notable exception. In the latter period, REITs listed on AMEX were significantly lower than those listed on NYSE.

While this study provides evidence on changes in REIT liquidity, it leaves much room for future research in this area. First would be to determine why the return variance of REITs declined so precipitously from 1990 to 1994 . We speculate that stabilization of the market for commercial real estate assets is largely responsible. During 1990, the commercial real estate market was in free fall with few properties transacting. The Resolution Trust Corporation was just gearing up and had yet to begin disposing of the remnants of the battered thrift industry. These factors created tremendous uncertainty about real estate asset value, which translated into greater variance of returns on those assets. By 1994, commercial real estate markets were well on the road to recovery, with numerous transactions reducing uncertainty about asset values, hence reducing the variance of return on those assets.

A second promising area of future research would be to test whether the determinants of REIT spreads and the variance of REIT returns are different from the determinants of spreads or return variance for typical stocks. It may well be true that spreads and the return variance for similar non-REIT stocks also declined from 1990 to 1994 . The data processing requirements for testing this hypothesis are formidable, however. 
A third promising area of future research would be to investigate the role of inside and outside block ownership in determining REIT spreads. Chiang and Venkatesh (1988) report a positive effect of insider holdings on dealer information costs but no effect for institutional holdings based upon a sample of 63 NYSE firms. It seems likely that an analysis of REITs would provide similar results. We leave these areas as promising paths for future research. 


\section{References}

Amihud, Y. and H. Mendelson, 1986, Asset Pricing and the Bid-Ask Spread, Journal of Financial Economics $17,223-249$.

Below, S., J. Kiely, and W. McIntosh, 1995, An Examination of Informed Traders and the Market Microstructure of Real Estate Investment Trusts, Journal of Real Estate Research10, 335-361.

Benston, G. and R. Hagerman, 1974, Determinants of Bid-Ask Spreads in the Over-the-Counter Market, Journal of Financial Economics 1, 353-364.

Bhasin, V., 1996, Liquidation Costs, Risk Measurement and Security Returns, Working Paper-Federal Reserve Board of Governors.

Chiang, R. and P. Venkatesh, 1988, Insider Holdings and Perceptions of Information Asymmetry: A Note, Journal of Finance 43, 1041-1048.

Demsetz, H., 1968, The Cost of Transacting, Quarterly Journal of Economics 82, 33-53.

Easley, D. and M. O'Hara, 1987, Price, Trade Size, and Information in Securities Markets, Journal of Financial Economics 19, 69-90.

Glosten, L. and L. Harris, 1988, Estimating the Components of the Bid-Ask Spread, Journal of Financial Economics 21, 123-142.

Glosten, L. and P. Milgrom, 1985, Bid, Ask and Transaction Prices in a Specialist Market with Heterogeneously Informed Traders, Journal of Financial Economics 14, 71-100.

Harris, L., 1989, A Day-End Transaction Price Anomoly, Journal of Financial and Quantitative Analysis 24, 2945.

Kadlec, G, and J. McConnell, 1994, The Effect of Market Segmentation and Illiquidity on Asset Prices: Evidence from Exchange Listings, Journal of Finance 49, 611-36.

Kyle, A., 1985, Continuous Auctions and Insider Trading, Econometrica 53, 1315-35.

NAREIT, REIT Handbook, 1992 and 1995 eds., National Association of Real Estate Investment Trusts: Washington, DC.

Nelling, E., J. Mahoney, T. Hildebrand, and M. Goldstein, 1995, Real Estate Investment Trusts, Small Stocks, and Bid-ask Spreads, Real Estate Economics 23, 45-63.

Sanger, G. and J. McConnell, 1986, Stock Exchange Listing, Firm Value, and Security Market Efficiency: The Impact of the NASDAQ, Journal of Financial and Quantitative Analysis 21, 1-25.

Stoll, H., 1978, The Pricing of Security Dealer Services: An Empirical Study of NASDAQ Stocks, Journal of Finance 33, 1153-1172.

Tinic, S. and R. West, 1972, Competition and the Pricing of Dealer Service in the Over-the-Counter Stock Market, Journal of Financial and Quantitative Analysis 7, 1707-1727. 
Table 1

Number and market capitalization of 1990 and 1994 sample REITs by asset type and by exchange

(Percentages of yearly totals appear in parentheses)

\begin{tabular}{|c|c|c|c|c|}
\hline & \multicolumn{2}{|c|}{1990} & \multicolumn{2}{|c|}{1994} \\
\hline & $\begin{array}{l}\text { Number } \\
\text { of } \\
\text { REITs }\end{array}$ & $\begin{array}{c}\text { Market } \\
\text { Capitalizatio } \\
n \\
\text { (\$ billions) }\end{array}$ & $\begin{array}{l}\text { Number } \\
\text { of } \\
\text { REITs }\end{array}$ & $\begin{array}{c}\text { Market } \\
\text { capitalization } \\
\text { (\$ billions) }\end{array}$ \\
\hline A11 REITs & $\begin{array}{c}117 \\
(100 \%)\end{array}$ & $\begin{array}{c}\$ 8.7 \\
(100 \%)\end{array}$ & $\begin{array}{c}223 \\
(100 \%)\end{array}$ & $\begin{array}{c}\$ 44.6 \\
(100 \%)\end{array}$ \\
\hline \multicolumn{5}{|c|}{ Panel A: REITs by exchange } \\
\hline NYSE & $\begin{array}{c}52 \\
(44 \%)\end{array}$ & $\begin{array}{l}\$ 6.4 \\
(74 \%)\end{array}$ & $\begin{array}{c}138 \\
(62 \%)\end{array}$ & $\begin{array}{l}\$ 40.5 \\
(91 \%)\end{array}$ \\
\hline AMEX & $\begin{array}{c}40 \\
(34 \%)\end{array}$ & $\begin{array}{l}\$ 1.5 \\
(17 \%)\end{array}$ & $\begin{array}{c}61 \\
(27 \%)\end{array}$ & $\begin{array}{l}\$ 2.7 \\
(6 \%)\end{array}$ \\
\hline NASDAQ & $\begin{array}{c}25 \\
(22 \%)\end{array}$ & $\begin{array}{l}\$ 0.8 \\
(9 \%)\end{array}$ & $\begin{array}{c}24 \\
(11 \%)\end{array}$ & $\begin{array}{l}\$ 1.4 \\
(3 \%)\end{array}$ \\
\hline \multicolumn{5}{|c|}{$\begin{array}{l}\text { Panel B: REITs by asset } \\
\text { type }\end{array}$} \\
\hline Equity & $\begin{array}{c}58 \\
(49 \%)\end{array}$ & $\begin{array}{l}\$ 5.6 \\
(64 \%)\end{array}$ & $\begin{array}{c}178 \\
(80 \%)\end{array}$ & $\begin{array}{l}\$ 39.3 \\
(88 \%)\end{array}$ \\
\hline Mortgage & $\begin{array}{c}43 \\
(37 \%)\end{array}$ & $\begin{array}{l}\$ 2.5 \\
(29 \%)\end{array}$ & $\begin{array}{c}27 \\
(12 \%)\end{array}$ & $\begin{array}{l}\$ 2.4 \\
(5 \%)\end{array}$ \\
\hline Hybrid & $\begin{array}{c}16 \\
(14 \%)\end{array}$ & $\begin{array}{l}\$ 0.6 \\
(7 \%)\end{array}$ & $\begin{array}{c}18 \\
(8 \%)\end{array}$ & $\begin{array}{l}\$ 2.9 \\
(7 \%)\end{array}$ \\
\hline
\end{tabular}


Table 2

Descriptive cross-sectional statistics for determinants of REIT bid-ask spreads as a percentage of share price

1990 and 1994

\begin{tabular}{|c|c|c|c|c|}
\hline \multirow{2}{*}{ Variable } & \multicolumn{2}{|c|}{1990} & \multicolumn{2}{|c|}{1994} \\
\hline & Mean & Std. Error & Mean & Std. Error \\
\hline $\begin{array}{l}\text { Variance of Returns } \\
\text { (percent) }\end{array}$ & 17.55 & 3.13 & 6.67 & 1.04 \\
\hline $\begin{array}{l}\text { Volume } \\
\text { (thousands of shares) }\end{array}$ & 10.88 & 0.95 & 30.51 & 2.15 \\
\hline $\begin{array}{l}\text { Turnover (percent of } \\
\text { market } \\
\text { capitalization) }\end{array}$ & 1.27 & 0.07 & 2.47 & 0.16 \\
\hline $\begin{array}{l}\text { Share Price } \\
\text { (dollars) }\end{array}$ & 9.01 & 0.59 & 14.82 & 0.56 \\
\hline $\begin{array}{l}\text { Market Value } \\
\text { (\$ millions) }\end{array}$ & 74.1 & 10.8 & 200.0 & 16.0 \\
\hline NYSE (percent) & 44.4 & 4.6 & 61.9 & 3.3 \\
\hline AMEX (percent) & 34.2 & 4.4 & 27.4 & 3.0 \\
\hline NASDAQ (percent) & 20.5 & 3.7 & 10.8 & 2.1 \\
\hline Equity (percent) & 49.6 & 4.6 & 79.8 & 2.7 \\
\hline Mortgage (percent) & 36.8 & 4.5 & 12.1 & 2.2 \\
\hline Hybrid (percent) & 13.7 & 3.2 & 8.1 & 1.8 \\
\hline
\end{tabular}


Table 3

REIT bid-ask spreads, as a percentage of share price by asset type and by exchange 1990 and 1994

\begin{tabular}{|c|c|c|c|c|}
\hline & \multicolumn{2}{|c|}{1990 Sample } & \multicolumn{2}{|c|}{1994 Sample } \\
\hline & Mean & $\begin{array}{l}\text { Standard } \\
\text { Error }\end{array}$ & Mean & $\begin{array}{l}\text { Standard } \\
\text { Error }\end{array}$ \\
\hline A11 REITs & 5.63 & 0.58 & 4.30 & 0.37 \\
\hline \multicolumn{5}{|c|}{ Panel A: REITs by exchange } \\
\hline NYSE & 3.88 & 0.55 & 3.43 & 0.45 \\
\hline AMEX & 4.43 & 0.55 & 4.87 & 0.61 \\
\hline NASDAQ & 11.64 & 2.00 & 7.70 & 1.52 \\
\hline \multicolumn{5}{|c|}{$\begin{array}{l}\text { Panel B: REITs by asset } \\
\text { type }\end{array}$} \\
\hline Equity & 4.49 & 0.65 & 3.47 & 0.32 \\
\hline Mortgage & 6.02 & 0.87 & 6.95 & 1.25 \\
\hline Hybrid & 8.61 & 2.48 & 8.56 & 2.31 \\
\hline
\end{tabular}


Table 4

REIT bid-ask spreads, in dollars

by asset type and by exchange

1990 and 1994

\begin{tabular}{lcccc}
\hline & \multicolumn{2}{c}{ 1990 Sample } & \multicolumn{2}{c}{ 1994 Sample } \\
\hline & Mean & $\begin{array}{c}\text { Standard } \\
\text { Error }\end{array}$ & Mean & $\begin{array}{c}\text { Standard } \\
\text { Error }\end{array}$ \\
\hline All REITs & 0.30 & 0.02 & 0.35 & 0.01 \\
\hline Panel A: REITs by exchange & & & & \\
\hline NYSE & 0.24 & 0.01 & 0.35 & 0.01 \\
AMEX & 0.22 & 0.01 & 0.28 & 0.02 \\
NASDAQ & 0.58 & 0.09 & 0.51 & 0.07 \\
& & & & \\
\hline $\begin{array}{l}\text { Panel B: REITs by asset } \\
\text { type }\end{array}$ & & & & 0.01 \\
\hline Equity & 0.34 & 0.04 & 0.36 & 0.04 \\
Mortgage & 0.23 & 0.02 & 0.31 & 0.04 \\
Hybrid & 0.33 & 0.06 & 0.36 & \\
\hline
\end{tabular}


Table 5

Spread costs of constructing equally and value-weighted REIT portfolios with $\$ 100$ market values 1990 versus 1994

by asset type and by exchange (Spreads in dollars)

\begin{tabular}{|c|c|c|c|c|c|c|}
\hline & \multicolumn{3}{|c|}{ Equally weighted portfolios } & \multicolumn{3}{|c|}{ Value weighted portfolios } \\
\hline & $\begin{array}{c}1990 \\
\text { Spread }\end{array}$ & $\begin{array}{c}1994 \\
\text { Spread }\end{array}$ & Difference & $\begin{array}{c}1990 \\
\text { Spread }\end{array}$ & $\begin{array}{c}1994 \\
\text { Spread }\end{array}$ & Difference \\
\hline All REITs & 3.29 & 2.36 & -0.93 & 2.39 & 2.00 & -0.39 \\
\hline \multicolumn{7}{|c|}{ Panel A: REITs by exchange } \\
\hline NYSE & 2.18 & 1.96 & -0.22 & 1.96 & 1.87 & -0.09 \\
\hline AMEX & 2.78 & 2.83 & 0.05 & 2.27 & 2.90 & 0.63 \\
\hline NASDAQ & 8.08 & 5.54 & -2.54 & 6.15 & 3.99 & -2.16 \\
\hline \multicolumn{7}{|c|}{ Panel B: REITs by asset type } \\
\hline Equity & 2.88 & 2.19 & -0.69 & 1.97 & 1.89 & -0.08 \\
\hline Mortgage & 3.57 & 3.70 & 0.13 & 2.66 & 3.47 & 0.81 \\
\hline Hybrid & 5.14 & 3.35 & -1.79 & 5.17 & 2.23 & -2.94 \\
\hline
\end{tabular}

Note: The equally weighted spread is the dollar spread that would be paid to construct a portfolio with a market value of $\$ 100$ containing an equal number of shares of each REIT trading in each group in a given year. The number of shares of each stock in an equally weighted portfolio is 100 divided by the sum of all REIT prices in the group. A stock's contribution to the portfolio dollar spread is the stock's dollar spread multiplied by the number of shares. These contributions are summed across all REITs in each group to obtain the equally weighted dollar spread. The value-weighted spread is the dollar spread that would be paid to construct a portfolio with a market value of $\$ 100$ allocated proportionally by the market capitalization across all REIT trading in each group in a given year. The number of shares of each stock in a value-weighted portfolio is 100 times the ratio of the stock's market capitalization to that of the group (to obtain the dollar investment per stock) and then dividing by the stock's price. A stock's contribution to the portfolio dollar spread is the stock's dollar spread multiplied by the number of shares. These contributions are summed across all REITs in each group in each year to obtain the value-weighted dollar spread. 
Table 6

Determinants of REIT bid-ask spreads

Univariate regression results for 1990 and 1994

Dependent variable is the bid-ask spread as a percentage of share price

( $t$-statistics appear in parentheses)

\begin{tabular}{|c|c|c|c|c|c|c|}
\hline \multirow[b]{2}{*}{ Variable } & \multicolumn{3}{|c|}{1990} & \multicolumn{3}{|c|}{1994} \\
\hline & Intercept & $\begin{array}{c}\text { Parameter } \\
\text { estimate }\end{array}$ & $\begin{array}{l}\text { Adjusted } \\
\mathrm{R}^{2}\end{array}$ & Intercept & $\begin{array}{c}\text { Parameter } \\
\text { estimate }\end{array}$ & $\begin{array}{c}\text { Adjusted } \\
\mathrm{R}^{2}\end{array}$ \\
\hline Variance of Return & $\begin{array}{r}3.05^{* *} \\
(7.7)\end{array}$ & $\begin{array}{l}0.15^{* \star *} \\
(13.9)\end{array}$ & 0.63 & $\begin{array}{r}2.56^{ \pm *} \\
(9.5)\end{array}$ & $\begin{array}{l}0.26^{ \pm *} \\
(16.4)\end{array}$ & 0.55 \\
\hline Volume & $\begin{array}{l}7.00^{* *} \\
(8.6)\end{array}$ & $\begin{array}{l}-0.13 \\
(-2.3)\end{array}$ & 0.04 & $\begin{array}{c}5.83^{* *} \\
(12.0)\end{array}$ & $\begin{array}{r}-0.05^{+*} \\
(-4.5)\end{array}$ & 0.08 \\
\hline Turnover & $\begin{array}{l}5.93^{* *} \\
(5.2)\end{array}$ & $\begin{array}{l}-0.24 \\
(-0.3)\end{array}$ & -0.01 & $\begin{array}{c}5.51^{* *} \\
(10.8)\end{array}$ & $\begin{array}{r}-0.49^{* *} \\
(-3.3)\end{array}$ & 0.04 \\
\hline Share Price & $\begin{array}{c}10.03^{* *} \\
(11.5)\end{array}$ & $\begin{array}{r}-0.49^{* *} \\
(-6.1)\end{array}$ & 0.25 & $\begin{array}{r}10.38^{* *} \\
(17.8)\end{array}$ & $\begin{array}{l}-0.41^{* *} \\
(-12.0)\end{array}$ & 0.39 \\
\hline Market Value & $\begin{array}{c}6.93^{* *} \\
(10.6)\end{array}$ & $\begin{array}{c}-0.017^{* *} \\
(-3.7)\end{array}$ & 0.10 & $\begin{array}{c}5.91^{* *} \\
(13.1)\end{array}$ & $\begin{array}{r}-0.008^{* *} \\
(-5.5)\end{array}$ & 0.12 \\
\hline NYSE & $\begin{array}{l}7.10^{* *} \\
(9.3)\end{array}$ & $\begin{array}{l}-3.22^{* *} \\
(-2.9)\end{array}$ & 0.06 & $\begin{array}{l}5.73^{* *} \\
(9.8)\end{array}$ & $\begin{array}{l}-2.30^{* *} \\
(-3.1)\end{array}$ & 0.04 \\
\hline AMEX & $\begin{array}{l}6.26^{* *} \\
(8.8)\end{array}$ & $\begin{array}{l}-1.83 \\
(-1.5)\end{array}$ & 0.01 & $\begin{array}{l}4.09^{* *} \\
(9.5)\end{array}$ & $\begin{array}{r}0.78 \\
(0.9)\end{array}$ & -0.00 \\
\hline NASDAQ & $\begin{array}{l}4.11^{* *} \\
(7.3)\end{array}$ & $\begin{array}{l}7.53^{* \star *} \\
(6.0)\end{array}$ & 0.24 & $\begin{array}{c}3.87^{+*} \\
(10.2)\end{array}$ & $\begin{array}{l}4.05^{ \pm * t} \\
(3.5)\end{array}$ & 0.05 \\
\hline Equity & $\begin{array}{l}6.73^{* t} \\
(8.4)\end{array}$ & $\begin{array}{l}-2.25 \\
(-2.0)\end{array}$ & 0.025 & $\begin{array}{l}7.46^{ \pm *} \\
(9.6)\end{array}$ & $\begin{array}{l}-3.97^{\text {t* }} \\
(-4.6)\end{array}$ & 0.05 \\
\hline Mortgage & $\begin{array}{l}5.41^{* *} \\
(7.4)\end{array}$ & $\begin{array}{r}0.61 \\
(0.5)\end{array}$ & -0.01 & $\begin{array}{c}3.94^{* *} \\
(10.2)\end{array}$ & $\begin{array}{l}3.01^{* *} \\
(2.7)\end{array}$ & 0.08 \\
\hline Hybrid & $\begin{array}{l}5.14^{* *} \\
(8.4)\end{array}$ & $\begin{array}{c}3.47^{*} \\
(2.1)\end{array}$ & 0.03 & $\begin{array}{c}3.93 \\
(10.5)\end{array}$ & $\begin{array}{l}4.63^{*+} \\
(3.5)\end{array}$ & 0.05 \\
\hline $\begin{array}{l}\text { Number of } \\
\text { observations }\end{array}$ & & 114 & & & 223 & \\
\hline $\begin{array}{l}{ }^{*} \text { Indicates statist } \\
\text { Indicates statist }\end{array}$ & nificanc & $\begin{array}{l}0.01 \text { level. } \\
0.05 \text { level. }\end{array}$ & & & & \\
\hline
\end{tabular}


Table 7

Determinants of REIT bid-ask spreads

Univariate regression results for 1990 and 1994

Dependent variable is the natural log of the bid-ask spread as a percentage of share price ( $t$-statistics appear in parentheses)

\begin{tabular}{|c|c|c|c|c|c|c|}
\hline \multirow[b]{2}{*}{ Variable } & \multicolumn{3}{|c|}{1990} & \multicolumn{3}{|c|}{1994} \\
\hline & Intercept & $\begin{array}{l}\text { Parameter } \\
\text { estimate }\end{array}$ & $\begin{array}{l}\text { Adjusted } \\
\mathrm{R}^{2}\end{array}$ & Intercept & $\begin{array}{l}\text { Parameter } \\
\text { estimate }\end{array}$ & $\begin{array}{c}\text { Adjusted } \\
\mathrm{R}^{2}\end{array}$ \\
\hline $\begin{array}{l}\ln \text { (Variance of } \\
\text { Return) }\end{array}$ & $\begin{array}{l}0.41^{* *} \\
(6.9)\end{array}$ & $\begin{array}{l}0.52^{* *} \\
(20.1)\end{array}$ & 0.78 & $\begin{array}{l}0.57^{+*} \\
(15.7)\end{array}$ & $\begin{array}{l}0.56^{* *} \\
(23.3)\end{array}$ & 0.71 \\
\hline $\ln$ (Volume) & $\begin{array}{l}1.75^{* *} \\
(11.6)\end{array}$ & $\begin{array}{l}-0.20^{* *} \\
(-2.9)\end{array}$ & 0.06 & $\begin{array}{l}1.67^{* *} \\
(16.2)\end{array}$ & $\begin{array}{l}-0.23^{* *} \\
(-6.8)\end{array}$ & 0.17 \\
\hline ln (Turnover) & $\begin{array}{l}1.38^{* *} \\
(18.6)\end{array}$ & $\begin{array}{l}-0.15 \\
(-1.4)\end{array}$ & 0.01 & $\begin{array}{l}1.27^{*+*} \\
(21.7)\end{array}$ & $\begin{array}{l}-0.39^{* *} \\
(-6.7)\end{array}$ & 0.17 \\
\hline Ln(Share Price) & $\begin{array}{l}2.84^{* *+} \\
(28.0)\end{array}$ & $\begin{array}{l}-0.77^{\text {*** }} \\
(-15.9)\end{array}$ & 0.69 & $\begin{array}{l}2.88^{* *} \\
(40.6)\end{array}$ & $\begin{array}{l}-0.76^{* * *} \\
(-27.6)\end{array}$ & 0.77 \\
\hline In (Market Value) & $\begin{array}{l}2.87^{* *} \\
(22.7)\end{array}$ & $\begin{array}{l}-0.43^{* *} \\
(-12.8)\end{array}$ & 0.59 & $\begin{array}{l}2.76^{* *} \\
(24.3)\end{array}$ & $\begin{array}{l}-0.38^{* *} \\
(-15.9)\end{array}$ & 0.53 \\
\hline NYSE & $\begin{array}{l}1.62^{*+} \\
(17.0)\end{array}$ & $\begin{array}{l}-0.55^{* *} \\
(-3.9)\end{array}$ & 0.11 & $\begin{array}{l}1.41^{* *} \\
(17.6)\end{array}$ & $\begin{array}{l}-0.59^{* *} \\
(-5.8)\end{array}$ & 0.13 \\
\hline AMEX & $\begin{array}{l}1.42^{* *} \\
(15.5)\end{array}$ & $\begin{array}{l}-0.16 \\
(-1.0)\end{array}$ & -0.00 & $\begin{array}{l}0.97^{* *} \\
(15.7)\end{array}$ & $\begin{array}{r}0.30 \\
(2.5)\end{array}$ & 0.02 \\
\hline NASDAQ & $\begin{array}{l}1.16^{* *} \\
(16.4)\end{array}$ & $\begin{array}{l}1.06^{* *} \\
(6.7)\end{array}$ & 0.28 & $\begin{array}{l}0.96^{* *} \\
(18.0)\end{array}$ & $\begin{array}{l}0.83^{* *} \\
(5.1)\end{array}$ & 0.10 \\
\hline Equity & $\begin{array}{l}1.59^{* *} \\
(15.8)\end{array}$ & $\begin{array}{l}-0.44^{* *} \\
(-3.1)\end{array}$ & 0.07 & $\begin{array}{l}1.61^{* *} \\
(14.6)\end{array}$ & $\begin{array}{l}-0.70^{* *} \\
(-5.7)\end{array}$ & 0.12 \\
\hline Mortgage & $\begin{array}{l}1.29^{* *} \\
(13.8)\end{array}$ & $\begin{array}{r}0.23 \\
(1.5)\end{array}$ & 0.01 & $\begin{array}{l}0.97^{* *} \\
(17.8)\end{array}$ & $\begin{array}{l}0.62^{* *} \\
(3.9)\end{array}$ & 0.06 \\
\hline Hybrid & $\begin{array}{l}1.30^{* *} \\
(16.6)\end{array}$ & $\begin{array}{l}0.48 \\
(2.3)\end{array}$ & 0.04 & $\begin{array}{l}0.99^{* *} \\
(18.4)\end{array}$ & $\begin{array}{l}0.65^{* *} \\
(3.4)\end{array}$ & 0.05 \\
\hline $\begin{array}{l}\text { Number of } \\
\text { observations }\end{array}$ & & 114 & & & 223 & \\
\hline $\begin{array}{l}\text { ** Indicates stati } \\
\text { Indicates statis }\end{array}$ & $\begin{array}{l}\text { iificance } \\
\text { ificance }\end{array}$ & $\begin{array}{l}0.01 \text { level. } \\
0.05 \text { level. }\end{array}$ & & & & \\
\hline
\end{tabular}


Table 8

Determinants of REIT bid-ask spreads

Pooled multivariate regression results for 1990 and 1994

Dependent variable is the bid-ask spread as a percentage of share price

( $t$-statistics appear in parentheses)

\begin{tabular}{|c|c|c|c|}
\hline Variable & 1990 & 1994 & $t$-test ${ }^{\mathrm{a}}$ \\
\hline Intercept & $\begin{array}{l}6.92^{* *} \\
(6.7)\end{array}$ & $\begin{array}{l}7.91^{* *} \\
(7.4)\end{array}$ & 0.8 \\
\hline Variance of Returns & $\begin{array}{c}0.12^{* *} \\
(12.0)\end{array}$ & $\begin{array}{c}0.19^{* * *} \\
(12.0)\end{array}$ & $3.5^{* *}$ \\
\hline Volume & $\begin{array}{l}-0.05 \\
(-1.1)\end{array}$ & $\begin{array}{l}-0.02 \\
(-1.9)\end{array}$ & 0.6 \\
\hline Turnover & $\begin{array}{l}-0.37 \\
(-0.7)\end{array}$ & $\begin{array}{l}-0.01 \\
(-0.1)\end{array}$ & 0.7 \\
\hline Share Price & $\begin{array}{r}-0.35^{* *} \\
(-4.8)\end{array}$ & $\begin{array}{r}-0.28 \\
(-6.6)\end{array}$ & 0.9 \\
\hline Market Value & $\begin{array}{l}0.007 \\
(1.7)\end{array}$ & $\begin{array}{r}0.002 \\
(1.2)\end{array}$ & -1.2 \\
\hline AMEX & $\begin{array}{l}0.12 \\
(0.2)\end{array}$ & $\begin{array}{l}-2.23^{* *} \\
(-3.8)\end{array}$ & $-2.5^{*}$ \\
\hline NASDAQ & $\begin{array}{l}3.79^{* *} \\
(4.2)\end{array}$ & $\begin{array}{l}0.11 \\
(0.1)\end{array}$ & $-3.0^{* *}$ \\
\hline Mortgage & $\begin{array}{l}-0.77 \\
(-1.1)\end{array}$ & $\begin{array}{c}0.66 \\
(0.9)\end{array}$ & 1.4 \\
\hline Hybrid & $\begin{array}{c}-2.24 \\
(-2.3)\end{array}$ & $\begin{array}{l}1.60 \text { * } \\
(2.0)\end{array}$ & $3.1^{* * *}$ \\
\hline
\end{tabular}

Number of observations: 337

Adjusted $\mathrm{R}^{2}$ : 0.71

a Test statistic for a test of whether the variable coefficient for 1994 is significantly different than that for 1990.

** Indicates statistical significance at the 0.01 level.

Indicates statistical significance at the 0.05 level. 


\section{Table 9}

Determinants of REIT bid-ask spreads

Pooled multivariate regression results for 1990 and 1994

Dependent variable is the natural logarithm of the bid-ask spread as a percentage of share price ( $t$-statistics appear in parentheses)

\begin{tabular}{|c|c|c|c|}
\hline Variable & 1990 & 1994 & $t$-test ${ }^{\mathrm{a}}$ \\
\hline Intercept & $\begin{array}{l}1.89^{* *} \\
(9.7)\end{array}$ & $\begin{array}{c}2.40 \\
(11.9)\end{array}$ & $2.1^{*}$ \\
\hline $\ln$ (Variance of Returns) & $\begin{array}{l}0.24^{* *} \\
(6.2)\end{array}$ & $\begin{array}{l}0.19^{* *} \\
(6.7)\end{array}$ & -1.1 \\
\hline $\ln$ (Volume) & $\begin{array}{c}-0.09 \\
(-1.1)\end{array}$ & $\begin{array}{c}-0.02 \\
(-0.1)\end{array}$ & 0.5 \\
\hline ln (Turnover) & $\begin{array}{c}0.01 \\
(0.2)\end{array}$ & $\begin{array}{l}-0.16 \\
(-1.2)\end{array}$ & -1.1 \\
\hline $\ln ($ Share Price $)$ & $\begin{array}{l}-0.44^{* *} \\
(-5.1)\end{array}$ & $\begin{array}{l}-0.42^{* *} \\
(-3.4)\end{array}$ & 0.1 \\
\hline ln (Market Value) & $\begin{array}{l}-0.01 \\
(-0.1)\end{array}$ & $\begin{array}{c}-0.07 \\
(-0.6)\end{array}$ & -0.5 \\
\hline AMEX & $\begin{array}{l}-0.08 \\
(-1.2)\end{array}$ & $\begin{array}{l}-0.35^{* *} \\
(-5.8)\end{array}$ & $-3.0^{* *}$ \\
\hline NASDAQ & $\begin{array}{l}0.45^{\text {** }} \\
(5.2)\end{array}$ & $\begin{array}{l}0.29^{\text {** }} \\
(4.2)\end{array}$ & -1.4 \\
\hline Mortgage & $\begin{array}{l}-0.02 \\
(-0.2)\end{array}$ & $\begin{array}{c}0.06 \\
(1.0)\end{array}$ & 0.9 \\
\hline Hybrid & $\begin{array}{l}-0.10 \\
(-1.2)\end{array}$ & $\begin{array}{c}0.06 \\
(0.9)\end{array}$ & 1.5 \\
\hline
\end{tabular}

Number of observations: 337

Adjusted R': 0.89

a Test statistic for a test of whether the variable coefficient for 1994 is significantly different than that for 1990.

* Indicates statistical significance at the 0.01 level.

* Indicates statistical significance at the 0.05 level. 